\title{
Caspase-3 Activity as a Prognostic Factor in Colorectal Carcinoma
}

\author{
Liesbeth E. Jonges, J. Fred Nagelkerke, N. Geeske Ensink, Edo A. van der Velde, \\ Rob A. E. M. Tollenaar, Gert Jan Fleuren, Cornelis J. H. van de Velde, \\ Hans Morreau, and Peter J. K. Kuppen
}

Department of Pathology (LEJ, GJF, HM), Department of Surgery (LEJ, NGE, RAEMT, CJHV, PJKK), and Department of Medical Statistics (EAV), Leiden University Medical Center, Leiden; and Department of Toxicology (JFN), Leiden Amsterdam Center for Drugs Research, Leiden, The Netherlands

SUMMARY: Several techniques to determine apoptotic frequencies in tumors have been described. In this study, we report that biochemical detection of enzymatic caspase-3 activity is a simple and quantitative technique to measure apoptosis in colorectal tumor cells. The relevance of the level of apoptosis in colorectal cancer for the clinical course remains unclear. Therefore, we studied the correlation between caspase- 3 activity and prognosis of the disease in relation to different factors known to be involved in apoptosis induction. High caspase-3 activity significantly correlated with a higher risk of recurrence and was preferentially found in tumors of the right side of the colon. No correlation was detected between high caspase-3 activity and altered protein expression of p53, $\beta$-catenin, or proteins of mismatched repair genes. This indicates that high caspase- 3 activity has no evident correlation with the genetic Wnt-signaling or the mismatch repair mutational pathways. The caspase-3 activity significantly correlated with $\mathrm{CD} 57^{+}$tumor infiltrating cells. Therefore, high caspase- 3 activity in right-sided tumors might be induced by a specific lymphocytic reaction. (Lab Invest 2001, 81:681-688).

\begin{abstract}
A poptosis is an essential biologic process. As well as having a role in controlling cell number during early development, apoptosis is important for the removal of infected or genetically altered cells (Duke et al, 1996). Defects in the apoptotic mechanism are often found in neoplastic growth (Duke et al 1996; Green and Martin, 1995; Tompson, 1995), which is also the case in colorectal cancer (Evertsson et al, 1999; Gryfe et al, 1997; Tsujitani et al, 1996). Development of colorectal cancer proceeds through a series of genetic alterations that result in the activation of oncogenes and loss of tumor suppressor genes (Gryfe et al 1997; Rafter and Glinghammar, 1998; llyas et al, 1999). Mutations in genes known to be involved in cell cycle regulation, such as APC, p53, $\beta$-catenin, deleted in colorectal cancer (DCC), and K-ras, have been reported in colorectal cancer (reviewed in Gryfe et al, 1997). Furthermore, mutated genes involved in DNA mismatch repair can contribute to tumor growth. Alterations in these mismatch repair genes will lead to a microsatellite instability phenotype (MSI) (reviewed in Lothe, 1997). During tumorigenesis one of the target genes that is preferentially inactivated due to MSI is transforming growth factor $\beta$ receptor II (TGF $\beta$ RII) (Markowitz et al, 1995; Akiyama et al, 1996). Inactivation of TGF $\beta$ RII on cells down-regulates the suppres-
\end{abstract}

Received November 22, 2000.

Address reprint requests to: Dr. Peter J. K. Kuppen, Leiden University Medical Center, Surgery Oncology-Laboratory for Immunotherapy, LO-R, P.O. Box 9600, 2300 RC Leiden, The Netherlands. E-mail: kuppen@lumc.nl sive function of TGF $\beta$ on cell proliferation and in that way also results in disturbance of growth control (DeVisser and Kast, 1999). Most of the hereditary nonpolyposis colorectal tumors (HNPCC) exhibit MSI, whereas in sporadic colorectal cancers only $3 \%$ to $10 \%$ show this phenotype. This low rate of MSI in sporadic colorectal cancers seems to be caused by somatic inactivation of hMLH1 (Lothe, 1997).

As well as the occurrence of apoptosis in cells caused by intrinsic factors, apoptosis can also be induced by cells of the immune system to kill virally infected or transformed target cells via Fas ligation, exocytosis of granules, or production of toxic cytokines such as tumor necrosis factor (TNF)- $\alpha$ (Atkinson and Bleackley, 1995; Berke, 1995; Famularo et al, 1994; Warren and Smyth, 1999).

Thus, apoptosis can be induced in tumor cells as a result of both genetic alterations or an attack by immune cells. It is evident that the frequency of apoptosis in tumor tissue may have an impact on the outcome of the disease. Therefore, knowledge of the different induction pathways of apoptosis in colorectal cancer and its relationship to disease progression might contribute to the development of a specific therapy. In this study we investigate the possible role of apoptosis as a prognostic factor in colorectal carcinoma and its underlying mechanism. Caspase- 3 activity in colorectal carcinoma was studied as an indicator of tumor cell apoptosis, and the enzyme activity level was correlated with clinical parameters. The relationships between apoptosis and tumor size, proliferative capacity, tumor infiltration by cells of the 
immune system, and alterations of genes of the Wnt and mismatch repair (MMR) pathway were investigated to determine the possible inducers of apoptosis in a group of patients with sporadic colorectal cancer.

\section{Results}

\section{Determination of Caspase-3 Activity in Colorectal Cancer Specimens}

One of the central steps in apoptotic cell death is activation of caspases. Caspase- 3 is known to be a key enzyme during apoptosis. We determined caspase-3 activity in colorectal cancer tissue by in vitro measurement of its enzyme activity. As a control, caspase- 3 activity in normal colon tissue was determined. The caspase- 3 activity in 60 colorectal tumors ranged from 37 to $13,377 \mathrm{pmol} \mathrm{AMC} / \mathrm{minute} / \mathrm{mg}$ tumor tissue, with a mean value of $1344 \mathrm{pmol}$ AMC/ minute/mg tumor tissue. The activity in normal tissue ( $n=10$ ) was $28 \pm 18 \mathrm{pmol} \mathrm{AMC} / \mathrm{minute} / \mathrm{mg}$ tissue.

\section{High Caspase-3 Activity in Colorectal Cancer Is Correlated with a Higher Risk of Disease Recurrence}

To determine if caspase- 3 activity as a measure of apoptotic cell death had prognostic value in colorectal cancer, the enzyme activity was matched with clinical parameters. We found that high caspase-3 activity in the tumors significantly correlated with a higher risk of distant recurrence (Fig. 1). Other clinical parameters, such as age, sex, tumor stage, presence of metastases, overall survival related to disease, or all-cause mortality, did not correlate with caspase-3 activity (results not shown). The apoptotic tumor cell death did not seem to be the result of a high proliferation rate of these tumors as tested using immunohistochemical staining for the proliferation marker Ki-67 in five tumors showing the highest caspase- 3 activity $(>1375$ pmol AMC/minute/mg tumor tissue) and five tumors with the lowest caspase-3 activity ( $<338$ pmol AMC/ minute/mg tumor tissue). Tumors with low caspase-3 activity showed $47 \pm 21 \% \mathrm{Ki}-67$ expression, whereas tumors with high caspase- 3 activity had $71 \pm 20 \%$ expression of the proliferation marker. This difference was not significant ( $t$ test; $p=0.21$ ). Furthermore, tumor caspase-3 activity did not significantly correlate with the size of the tumors (Pearson correlation, $p=$ 0.43).

Next, we determined the relationship between caspase-3 activity and the number of apoptotic cells in the tumor tissue. Five tumors showing high caspase activity ( $>1375 \mathrm{pmol}$ AMC/minute/mg tumor tissue) and five tumors showing low caspase-3 activity $(<$ $338 \mathrm{pmol}$ AMC/minute/mg tumor tissue) were immunohistochemically stained for the caspase-3 cleavage product of the keratin 18 protein (M30). A typical example of this staining is shown in Figure 2. The number of $\mathrm{M} 30^{+}$apoptotic cells $/ \mathrm{mm}^{2}$ tumor tissue significantly correlated with the caspase-3 activity. The results in Figure 3 show that the expression of the keratin 18 cleavage product in tumors with a high caspase- 3 activity, as measured using the enzymatic method, was significantly higher than that of tumors with low caspase-3 activity. This confirms that caspase- 3 activity in colorectal tumors correlated with apoptotic tumor cell death. However, caspase-3 activity was not strictly related to the number of apoptotic cells present in the tumor, because the tumor showing the highest caspase-3 activity did not contain the most apoptotic cells (Fig. 3). This may indicate differences in activity of caspase-3 among tumor cells.

\section{Correlation between Tumor Infiltrating Cells and Apoptosis}

Lymphocytes can induce apoptosis in target cells. We therefore tested if the number of tumor-infiltrating

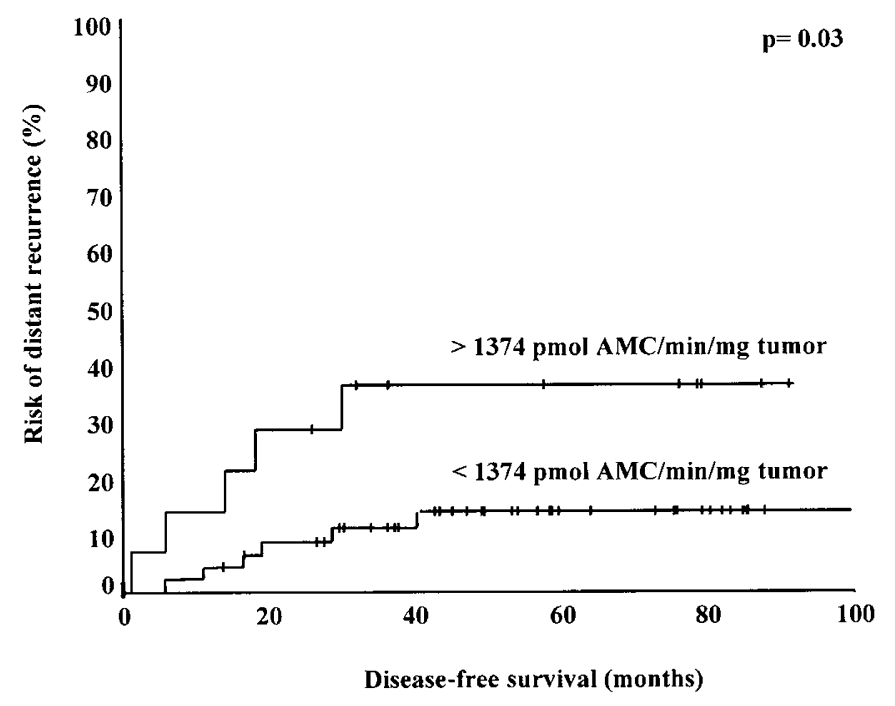

Figure 1.

High caspase- 3 activity is correlated to a higher risk of recurrence. Caspase- 3 activity $(<1374 \mathrm{pmol}$ AMC/minute/mg tumor tissue and $>1374 \mathrm{pmol}$ AMC/minute/mg tumor tissue [75th percentile]) was related to recurrence-free survival using Kaplan-Meier method. The risk of recurrence for the two caspase-3 activity groups is plotted. The difference between the Kaplan-Meier curves was calculated using the log rank test. A p-value $<0.05$ was considered to be significant. 


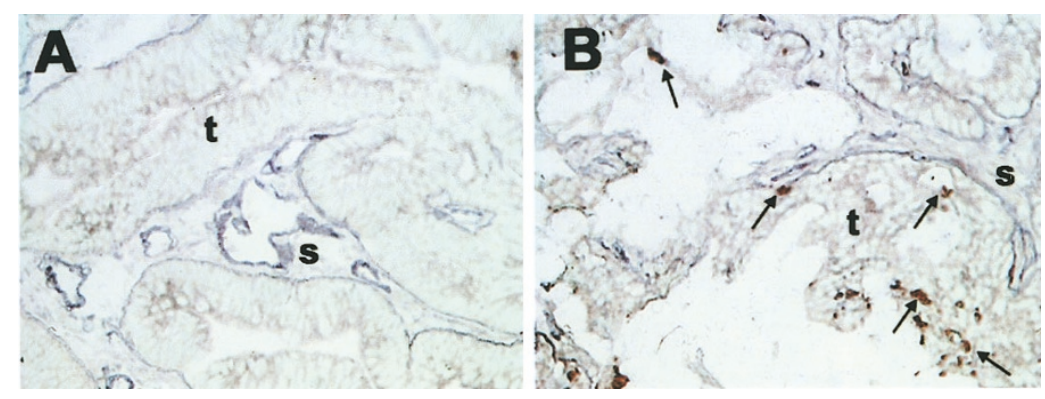

Figure 2.

Immunohistochemical detection of apoptotic tumor cells. Apoptotic tumor cells were immunohistochemically detected with M30, a cleavage product of keratin 18 and a marker for apoptotic epithelial cell death. An example of M30 staining of a low caspase-3 active tumor ( $87 \mathrm{pmol}$ AMC/minute/mg tumor) (A) and a high caspase-3 active tumor (2021 pmol AMC/minute/mg tumor) (B) are shown. Tumor $(t)$ and stroma $(s)$ are indicated. The stromal part is distinguished from tumor cells by laminin expression (blue). Examples of ${\mathrm{M} 30^{+}}^{+}$tumor cells (brown) present in the high caspase-3 active tumor are indicated with arrows.

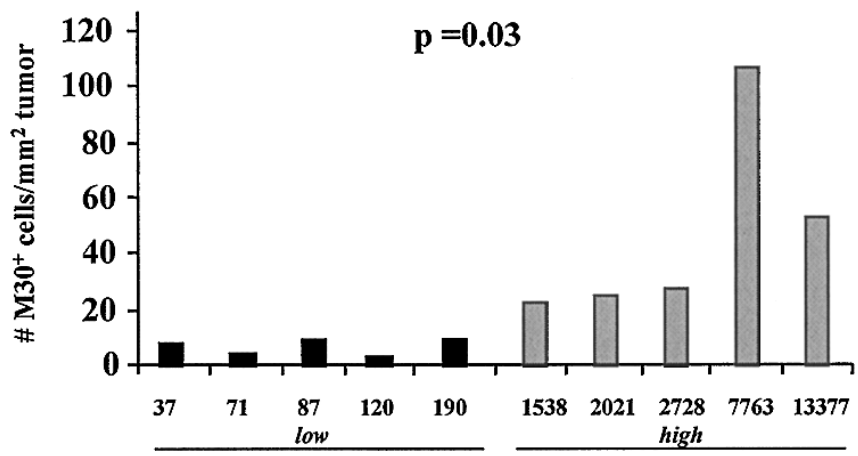

Caspase-3 activity (pmol/AMC/min/mg tumor)

Figure 3.

Enzymatic caspase-3 activity correlates with the frequency of apoptotic cells. Five tumors with low caspase-3 activity ( $<338$ pmol AMC/minute/mg tumor tissue) and five tumors with high caspase-3 activity ( $>1374 \mathrm{pmol} \mathrm{AMC/minute/mg} \mathrm{tumor} \mathrm{tissue)} \mathrm{were} \mathrm{immmunohistochemically} \mathrm{stained} \mathrm{for} \mathrm{M30,} \mathrm{a} \mathrm{cleavage} \mathrm{product} \mathrm{of} \mathrm{keratin}$

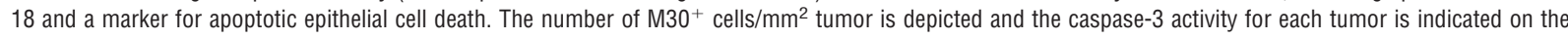
$x$-axis. A $t$ test showed significant differences between the low and high caspase-3 activity groups $(p=0.03)$.

lymphocytes correlated with caspase-3 activity observed in the tumors. Numbers of CD45 ${ }^{+}, \mathrm{CD}_{56}{ }^{+}$, and $\mathrm{CD} 7^{+}$lymphocytes present in tumor nests, and therefore in direct contact with tumor cells, were counted and compared with caspase-3 tumor activity. The results in Table 1 show that no significant relationships were found between $\mathrm{CD}_{4}{ }^{+}$or $\mathrm{CD}^{+} 6^{+}$ tumor-infiltrating cells and caspase- 3 activity, but that the number of tumor infiltrating $\mathrm{CD}^{+} 7^{+}$cells significantly correlated with caspase- 3 activity. More CD57 ${ }^{+}$

Table 1. Correlation between the Level of Caspase-3 Activity of Colorectal Specimens and the Number of Tumor Infiltrating Cells

\begin{tabular}{ccc}
\hline $\begin{array}{c}\text { Correlation between } \\
\text { markers }\end{array}$ & $\begin{array}{c}\text { Pearson correlation } \\
\text { coefficient }\end{array}$ & p-value \\
\hline CD45 and caspase-3 activity & 0.082 & 0.54 \\
CD56 and caspase-3 activity & 0.024 & 0.86 \\
CD57 and caspase-3 activity & 0.275 & $0.03^{\star}$ \\
\hline
\end{tabular}

The number of $\mathrm{CD} 45^{+}, \mathrm{CD} 56^{+}$, and $\mathrm{CD} 57^{+}$cells infiltrating tumor nests were related to caspase- 3 activity of the tumor using Pearson correlation. The Pearson correlation coefficient and $p$-value are depicted for the different combinations.

* indicates significant correlation. cells were related to higher caspase- 3 activity $(p=$ 0.03 ). An even stronger significant relationship was found when the high caspase-3 activity group ( $>1374$ $\mathrm{pmol} \mathrm{AMC} / \mathrm{minute} / \mathrm{mg}$ tumor tissue) was compared with the group with high CD57 infiltration ( $>0.4$ cells/ $\mathrm{mm}^{2}$ tumor): Pearson $\chi^{2}$ test, $p=0.001$. No significant correlation was found between the group of tumors with high caspase- 3 activity and the group with high CD $45^{+}$infiltrating cells ( $>27$ cells $/ \mathrm{mm}^{2}$ tumor) or with high $\mathrm{CD}^{+} 6^{+}$infiltrating cells $\left(>7\right.$ cells $/ \mathrm{mm}^{2}$ tumor). High $\mathrm{CD} 7^{+}$cell infiltration into tumor tissue was related to a higher risk of recurrence, such as high caspase-3 activity (log rank test; $p=0.03$ ). These results indicate a role for $\mathrm{CD} 57^{+}$cells in apoptosis in colorectal carcinomas.

\section{Correlation between Apoptosis and Genetic Background of Colorectal Tumors}

Eighteen of 60 (30\%) tumors were located in the right side of the bowel, and $50 \%$ of these right-sided tumors had a high caspase- 3 activity. In the group of left-side located tumors, only $14 \%$ showed high caspase- 3 activity. This correlation between high caspase-3 activity and right-sided location of tumors 
was significant (Pearson $\chi^{2}$ test; $p=0.007$ ) (Fig. 4). A correlation of right-sided colorectal tumors with intensively infiltrating lymphocytes has been described for tumors with a MSI phenotype (Gryfe et al, 2000; Loeb, 1994; Lothe, 1997). Furthermore, a high frequency of apoptosis has been shown in tumors with MSI (Dolcetti et al, 1999; Langlois et al, 1997). We investigated if there was a relationship between altered staining of the mismatch repair proteins hMLH1, hMSH2, and hMSH6 and caspase- 3 activity. Only three of the 60 (5\%) tumors showed no expression of MLH-1 with normal expression of hMSH2 and hMSH6. Two of these tumors were located in the right side of the colon, and only one tumor showed high caspase-3 activity. Exclusion of $\mathrm{MSI}^{+}$tumors from the study did not influence the correlation of high capsase-3 activity with a higher risk of recurrence (log rank test, $p<$ 0.04). All together, these results showed that high caspase- 3 activity was not directly linked to a MSI phenotype. Furthermore, we tested if altered p53 and $\beta$-catenin expression correlated with high caspase-3 activity. No significant correlation was found between p53 expression (Pearson $\chi^{2}$ test, $p=0.64$ ) or nuclear $\beta$-catenin expression (Pearson $\chi^{2}$ test, $p=0.23$ ) and high caspase-3 activity.

\section{Discussion}

In this study we showed that measurement of caspase-3 activity in frozen tissue of colorectal tumors can be used to quantify apoptosis in these carcinomas. The advantage of this method as compared with methods such as the TUNEL assay (Dolcetti et al, 1999; Evertsson et al, 1999; Hashimoto et al, 1997; Tsujitani et al, 1996), determination of apoptotic bodies on HE stainings (Ito et al, 1999), or flow cytometry (Watson et al, 1999) is that this is a quantitative method of determining apoptosis even before the phenotypic changes of these cells are clearly detectable.

We demonstrated that high caspase-3 activity was correlated with a higher risk of recurrence and, therefore, might be a prognostic factor in colorectal cancer. These findings are in line with two other studies that demonstrated that the frequency of apoptosis increased from Dukes' stage A, B, C to D (Evertsson et al, 1999), and from normal mucosa to adenoma and carcinoma (Baretton et al, 1996; Hawkins et al, 1997). These high apoptotic frequencies were not related to alterations in p53 function (Evertsson et al, 1999; Hawkins et al, 1997). This agreed with our data indicating no correlation between high caspase- 3 activity and altered $\mathrm{p} 53$ and $\beta$-catenin staining by immunohistochemistry. We were not able to detect significant differences between caspase-3 activity and Dukes' stage, but this was probably caused by the limited number of tumors of Dukes' stage $C$ relative to stage $B$ in our group.

Other studies reported an inverse relationship between apoptosis and survival: a low frequency of apoptosis was shown to predict a shorter survival time, either overall survival or risk of recurrence (Baretton et al, 1996; Bedi et al, 1995; Kawasaki et al, 1998; Langlois et al, 1997; Sugamura et al, 1998; Tsujitani et al, 1996). However, in contrast to our study, in some of these studies, relationships between mutations in p53 or bcl-2 and the presence of apoptosis were reported (Baretton et al, 1996; Langlois et al, 1997; Tsujitani et al, 1996). $\mathrm{MSI}^{+}$tumors are more often located in the right side of the colon, and show a high frequency of apoptosis (Dolcetti et al, 1999). Therefore, we tested if altered staining of MMR proteins was related to a high frequency of apoptosis, since high caspase-3 activity was preferentially observed in tumors located in the proximal part of the colon. However, only $5 \%$ of the tumors in our group showed an MMR-defective phenotype, in line with the frequency of MSI in sporadic colorectal cancer (Jass, 1999). In these cases only the expression of the $\mathrm{MLH}-1$ protein was affected, which has been described before as being the most frequent altered mismatch repair gene in sporadic cancers (Jass, 1999; Kane et al, 1997). Thus, mutations in the MMR genetic pathway were observed, but they did not match with the observed high caspase- 3 activity.

Lymphocytic infiltration into colorectal tumors has been shown to be of prognostic value (DiGiorgio et al, 1992; Jass, 1986; Ropponen et al, 1997; Svennevig et al, 1984). The location of infiltrating cells, either in the stromal part of the tumor or in tumor nests only, may be an important predictor of clinical outcome of colo-

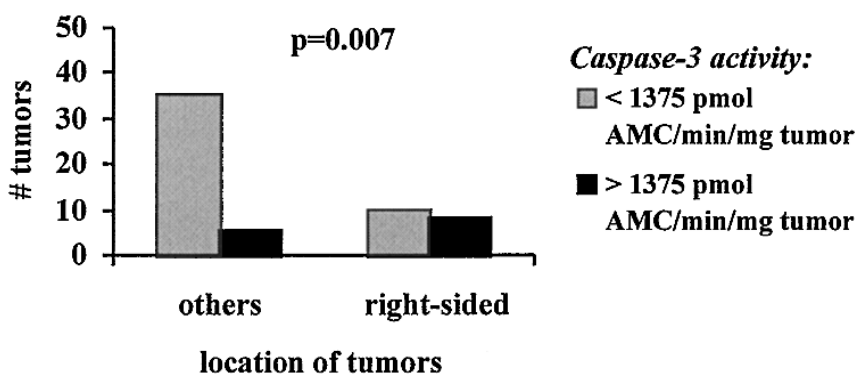

Figure 4.

High caspase-3 activity is preferentially detected in proximal tumors. Caspase- 3 activity $(<1374 \mathrm{pmol}$ AMC/minute/mg tumor tissue and $>1374 \mathrm{pmol}$ AMC/minute/mg tumor tissue [75th percentile]) was correlated with location of colon tumors. The number of tumors showing high or low caspase-3 activity is depicted for right-sided and other-located tumors. Correlation of caspase-3 activity and tumor location using Pearson $\chi^{2}$ test without Yates correction was made, and the $p$-value is indicated. A $p$-value $<0.05$ was considered to be significant. 
rectal cancer in the case of $\mathrm{CD}^{+} \mathrm{T}$ cells (Naito et al, 1998), and $\mathrm{CD}^{+} 6^{+}$and $\mathrm{CD}^{+} 7^{+}$cells (Jonges et al, submitted). We showed that high caspase- 3 activity is confined to $\mathrm{CD} 57^{+}$tumor infiltrating cells, but not to $\mathrm{CD}_{4} 5^{+}$or $\mathrm{CD}^{+}{ }^{+}$cells, indicating a role for the $\mathrm{CD} 57^{+}$ cells in mediating apoptosis. The exact role of CD57 still remains unclear, but this molecule has been shown to be expressed by $\mathrm{NK}, \mathrm{CD}^{+}$, and $\mathrm{CD}^{+}{ }^{+} \mathrm{T}$ cells. $T$ helper cells potentially produce cytokines, which might result in induction of apoptosis of tumor cells, whereas CD8 ${ }^{+}$T cells can mediate apoptosis by killing target cells. NK cells might induce tumor cell apoptosis via both cytokine production and cytotoxic responses. At the same time, tumor cells might inhibit a cytotoxic cellular response by production of immunosuppressive cytokines, such as TGF $\beta$ (DeVisser and Kast, 1999), or by expression of FasL (Hahne et al, 1996; O'Connell et al, 1996). In that case the immune response is likely to be inadequate, and only a proportion of tumor cells will undergo apoptosis. This apoptotic elimination of tumor cells might lead to a disturbance of the structural cohesion of the tumor, and multiple single cells may become detached and be released to the blood vessels or lymph ducts, resulting in metastases. In this way, apoptosis detected in the tumor might result in an early recurrence of the disease.

High apoptotic rates and high infiltration of cytotoxic lymphocytes showed to be a good prognosis for patients with $\mathrm{MSI}^{+}$colorectal tumors (Dolcetti et al, 1999), which seems in contradiction with our findings. However, high caspase-3 activity related to a higher risk of recurrence did not involve $\mathrm{MSI}^{+}$tumors. Therefore, the conclusions drawn in this study apply only to non- $\mathrm{MSI}^{+}$colorectal tumors.

Taken together, our results indicate that apoptosis in colorectal cancer has a prognostic value. As well as induction of apoptosis as the result of mutations in different tumorigenic pathways, we found indications that apoptosis in colorectal cancer is induced via a pathway in which specific lymphocytic tumor infiltration is initiated. This independent pathway will lead to a high frequency of apoptosis in these tumors, which possibly affects their growth by tumor tissue discohesion, leading to early recurrence of the disease. Tumors with this specific lymphocytic reaction showed a preference for right-sided location in the colon, but were non- $\mathrm{MSI}^{+}$. In the future, the different induction pathways for apoptosis in colorectal cancer should be investigated in further detail. This could result in the use of apoptosis as a prognostic marker and the development of more specific therapeutic strategies.

\section{Materials and Methods}

\section{Patients}

The study population consisted of 60 patients with colorectal cancer who had been treated between 1986 and 1994 at the Leiden University Medical Center (The Netherlands), for whom tissue specimens were available for analysis. These patients were identified through pathology records and had a 5-year follow-up history. Patients with tumor history other than in the colorectal region were excluded from this study. In the population were 35 women and 25 men, age ranging from 45 to 85 (mean 67) years. Records were reviewed to determine the stage of colorectal cancer by TNM classification (Sobin and Wittekind, 1997). Distribution of T stadium was as follows: $7 \%$ T1, 27\% T2, 60\% T3, and $6 \% \mathrm{~T} 4$, which was representative for all colorectal tumors collected in the Leiden University Medical Center in this time period; $77 \%$ of the tumors were located in the colon, and $23 \%$ in the rectum.

\section{Measurement of Caspase-3 Activity}

The enzymatic activity of caspase-3 (CPP32)proteases was measured as described (Blom et al, 1999). Cryostat sections of tumor tissue $10 \mu \mathrm{m}$ thick were suspended in $1 \mathrm{ml}$ ice-cold PBS and washed twice. The resulting pellet was resuspended in a lysis buffer consisting of $10 \mathrm{~mm}$ HEPES, pH 7.0, $40 \mathrm{~mm}$ $\beta$-glycerophosphate, $50 \mathrm{~mm} \mathrm{NaCl}, 2 \mathrm{~mm} \mathrm{MgCl}_{2}$, and 5 mM EGTA. After 10 minutes on ice the cells were disrupted by four cycles of freezing and thawing, and then stored at $-80^{\circ} \mathrm{C}$. Protein concentration was determined using the method described by Bradford (1976). For measurement, samples of $50 \mu \mathrm{g}$ protein were incubated with $40 \mathrm{nmol}$ of the enzyme substrate Ac-Asp-Glu-Val-sp-7-amino-4-methylcoumarin (DEVD-AMC) in a 100 mm HEPES buffer, pH 7.25, containing $10 \%(\mathrm{w} / \mathrm{v})$ sucrose, $0.1 \%$ (v/v) Nonidet $\mathrm{P} 40$, and $10 \mathrm{~mm}$ DTT. After cleavage of the substrate, fluorescent $A M C$ was released, which was monitored at an excitation of $360 \mathrm{~nm}$ and emission of $460 \mathrm{~nm}$ using a Perkin-Elmer plate-reader. Calibration curves were constructed using free AMC. Caspase- 3 activity was corrected for the number of tumor cells present, as microscopically determined in a sequential slide by surface measurement using an ocular grid. Caspase-3 activity was indicated in picomoles of AMC per minute per milligram of tumor tissue.

\section{Antibodies}

The following antibodies were used in the immunohistochemistry stainings. For frozen tissue: NCAM-16 (anti-CD56) (Becton and Dickinson, Woerden, The Netherlands), HNK-1 (anti-CD57; hybridoma obtained from ATCC), 4B2 (anti-CD45; hybridoma obtained from ATCC), polyclonal rabbit serum against human laminin (Heyl, Sanbio, Uden, The Netherlands) and M30 cytodeath (Boehringer Mannheim, Mannheim, Germany). For paraffin embedded tissue: DO7 (antiP53; Dako, Glostrup, Denmark), anti-MSH6 (Transduction Laboratories, Lexington), anti-MLH1 and antiMSH2 (Oncogene Research Products, Cambridge, UK), anti- $\beta$-catenin (Transduction Laboratories), TGF $\beta$ R2 (Santa Cruz Biotechnology, Santa Cruz, California). 


\section{Immunohistochemistry}

Frozen Tissue. Five-micrometer thick cryostat (Reichter Jung 2800 Frigocut, Leica, Nussloch, Germany) sections were cut from snap-frozen tumor tissue. Sections were air-dried for at least 16 hours at $60^{\circ} \mathrm{C}$. Subsequently, they were fixed in acetone for 10 minutes and washed twice in PBS. All dilutions of antibodies and conjugates were performed in PBS containing $1 \%(\mathrm{w} / \mathrm{v})$ BSA. After a 1-hour incubation with the primary antibody, the sections were washed in PBS three times for 5 minutes. Sections were incubated for 30 minutes with biotin-conjugated rabbit antimouse Ig (dilution 1:200; DAKO, Glostrup, Denmark), washed in PBS, and incubated with streptavidin biotinylated horseradish peroxidase (dilution 1:100; DAKO) for 30 minutes. After washing in PBS, visualization of immune complexes was performed by a 10-minute incubation with a 3,3'-diaminobenzidine (DAB) substrate solution containing $1.8 \times 10^{-3} \%(\mathrm{v} / \mathrm{v})$ $\mathrm{H}_{2} \mathrm{O}_{2}$. After the visualization with DAB substrate the sections were washed twice in PBS, and incubated with antilaminin antibodies on the same section for 30 minutes. After three washing steps with PBS, the sections were incubated for 30 minutes with biotinconjugated swine antirabbit lg. The immune complexes were visualized by a 12-minute incubation step in a buffered TRIS-HCL ( $\mathrm{pH} 7.6)$ solution containing, per $100 \mathrm{ml}$, (1) 40 mg 4-chloro-1-naphtol (Merck, Darmstadt, Germany) dissolved in $200 \mu$ l dimethyl formamide (Baker BV, Deventer, The Netherlands) and $300 \mu$ l ethanol (Merck), and (2) $100 \mu$ l of a $30 \%(\mathrm{v} / \mathrm{v})$ $\mathrm{H}_{2} \mathrm{O}_{2}$ solution (Merck). The sections were counterstained with hematoxylin (Histolab, Göteborg, Sweden).

Paraffin-Embedded Tissue. Immunohistochemistry was performed on 3- $\mu \mathrm{m}$ sections using aminopropylethoxysilane (APES)-coated slides. Paraffin sections were deparaffinized and rehydrated, and endogenous peroxidase was quenched with $0.3 \% \mathrm{H}_{2} \mathrm{O}_{2}$ in methanol for 20 minutes. Before incubation with the primary antibodies, the slides were subjected to antigen retrieval by submerging in a boiling solution of $10 \mathrm{~mm}$ citrate buffer, pH 6.0 (p53, MSH6), 10 mm citrate buffer with $0.05 \%$ DET (DishClean) ( $\beta$-catenin) or $1 \mathrm{~mm}$ EDTA (MLH1, MSH2) for 10 minutes in a microwave oven at $700 \mathrm{~W}$, and cooled down in this buffer to room temperature for 2 hours. For TGF $\beta$ R 2 no antigen retrieval was used. After washing in PBS, slides were incubated $\mathrm{o} / \mathrm{n}$ with the specific primary antibodies at room temperature. Visualization of the proteins was carried out as described for frozen tissue, except for MLH1 and $\mathrm{MSH} 2$ for which Envision peroxidase antimouse (DAKO) was used.

Immunohistochemical Evaluation. To determine the functional relevance of caspase-3 activity, the number of tumor cells expressing $\mathrm{M} 30$, the caspase cleavage product of keratin-18, were counted in 25 different grid-fields for five tumors showing low caspase-3 activity and five tumors showing high caspase-3 activity as determined with the enzyme assay as described above. To discriminate between tumor and stromal part, all sections were double-stained with M30 and laminin.

Changes in protein expression of genes potentially involved in tumorigenesis were analyzed by two observers. A tumor was depicted in the MMR pathway if lack of expression was detected for one or more of the proteins $\mathrm{MLH}-1, \mathrm{MSH}-2$, or MSH-6. Lymph nodes present in the tumor sections served as internal positive controls. For p53 staining, the fraction of tumor cells with intense positive nuclear expression was determined, and three different groups were determined: (1) no expression, (2) scattered expression $(<30 \%$ of tumor cells), and (3) homogeneous expression ( $>60 \%$ of tumor cells). For statistical analysis, groups 1 and 2 were considered as one group, because Kaserer et al (2000) described that scattered expression of p53 protein did not show any mutations. Mutations in the $\beta$-catenin gene result in increased nuclear expression with altered membrane expression (llyas et al, 1999). Three different expression patterns for $\beta$-catenin were scored: (1) membrane expression (no mutations), (2) nuclear expression in infiltrating front of the tumor, and (3) nuclear expression all over the tumor (Brabletz et al, 1998; Gunther et al, 1998).

To study the possible role of lymphocytes in induction of apoptosis of tumor cells, the number of lymphocytes within the tumor cell nests was counted using an ocular grid in sections double-stained for a lymphocyte marker and laminin. All countings were performed without prior knowledge of the clinical and molecular specifics of the tumor tissue. All positive cells present in the tumor cell nests within the grid, representing an area of $0.16 \mathrm{~mm}^{2}$, were counted. The percentage of the area occupied by tumor was determined for each grid-field. Discrimination between tumor and stromal tissue could be made based on laminin stainings: laminin was always expressed in the stromal part and not in tumor cell nests. For each staining, 25 different grid-fields within one section were counted. The amount of $\mathrm{CD} 57^{+}$cells was determined in the tumor cell nests, in the total tumor area, and in the stromal part of the tumor.

\section{Statistics}

Statistical analysis was performed using the computer program SPSS 9.0 (SPSS, Chicago, Illinois). Survival analysis was performed according to Kaplan-Meier, and differences between the survival curves were calculated using a log rank test. Correlations between continuous data were tested using Pearson correlation tests; for correlations between binary valued measurements, Pearson $\chi^{2}$ tests were used. To convert continuous data into binary-valued measurements, a cut-off point at the 75th percentile within the groups was used. Comparison of mean values between two groups were made using Student $t$ tests. For all tests, a $p$-value $<$ 0.05 was considered to be statistical significant. All tests used are indicated in the text and in the figure legends. 


\section{Acknowledgements}

The authors thank C. M. Janssen-Van Rhijn and H. J. G. M. de Bont for excellent technical assistance, and S. C. Bakker for a careful reading of the manuscript.

\section{References}

Akiyama $\mathrm{Y}$, Iwagana R, Ishakawa T, Sakamoto K, Nishi N, Nihei Z, Iwama T, Saitoh K, and Yuasa Y (1996). Mutations of the transforming growth factor- $\beta$ type II receptor gene are strongly related to sporadic proximal colon carcinomas with microsatellite instability. Cancer 78:2478-2484.

Atkinson EA and Bleackley RC (1995). Mechanisms of lysis by cytotoxic T cells. Crit Rev Immunol 15:359-384.

Baretton GB, Diebold J, Christoforis G, Müller C, Dopfer K, Schneiderbanger K, Schmidt M, and Löhrs U (1996). Apoptosis and immunohistochemical bcl-2 expression in colorectal adenomas and carcinomas: Aspects of carcinogenesis and prognostic significance. Cancer 77:255-264.

Bedi A, Pasricha PJ, Akhtar AJ, Barber JP, Bedi GC, Giardiello FM, Zehnbauer BA, Hamilton SR, and Jones RJ (1995). Inhibition of apoptosis during development of colorectal cancer. Cancer Res 55:1811-1816.

Berke G (1995). Unlocking the secrets of CTL and NK cells. Immunol Today 16:343-346.

Blom WM, de Bont $\mathrm{HJ}$, Meijerman I, Mulder GJ, and Nagelkerke JF (1999). Prevention of cycloheximide-induced apoptosis in hepatocytes by adenosine and by caspase inhibitors. Biochem Pharmacol 58:1891-1898.

Brabletz T, Jung A, Hermann K, Gunther K, Hohenberger W, and Kirchner T (1998). Nuclear overexpression of the oncoprotein beta-catenin in colorectal cancer is localized predominantly at the invasion front. Pathol Res Pract 194:701704.

Bradford MM (1976). A rapid and sensitive method for the quantitation of microgram quantities of protein utilizing the principle of protein-dye binding. Anal Biochem 72:248-254.

DeVisser KE and Kast WM (1999). Effects of TGF- $\beta$ on the immune system: Implications for cancer immunotherapy. Leukemia 13:1188-1199.

DiGiorgio A, Botti C, Tocchi A, Mingazzini P, and Flammia M (1992). The influence of tumor lymphocytic infiltration on long tem survival of surgically treated colorectal cancer patients. Int Surg 77:260.

Dolcetti R, Viel A, Doglioni C, Russo A, Guidoboni M, Capozzi E, Vecciato N, Macri E, Fornasarig M, and Boiocchi M (1999). High prevalence of activated intraepithelial cytotoxic T lymphocytes and increased neoplastic cell apoptosis in colorectal carcinomas with microsatellite instability. Am J Pathol 154:1805-1813.

Duke RC, Ojcius DM, and Ding-E Young J (1996). Cell suicide in health and disease. Sci Am 275:48-55.

Evertsson S, Bartik Z, Zhang $H$, Jansson A, and Sun XF (1999). Apoptosis in relation to proliferating cell nuclear antigen and Dukes' stage in colorectal adenocarcinoma. Int J Oncol 15:53-58.

Famularo G, De Simone C, Tzantzoglou S, and Trinchieri V (1994). Apoptosis, anti-apoptotic compounds and TNF- $\alpha$ release. Immunol Today 15:495-496.
Green DR and Martin SJ (1995). The killer and the executioner: How apoptosis controls malignancy. Curr Opin Immunol 7:694-703.

Gryfe R, Hyeja K, Hsieh ETK, Aronson MD, Holowaty EJ, Bull SB, Redston M, and Gallinger S (2000). Tumor microsatellite instability and clinical outcome in young patients with colorectal cancer. N Engl J Med 342:69-77.

Gryfe R, Swallow C, Bapat B, Redston M, Gallinger S, and Couture J (1997). Molecular biology of colorectal cancer. Curr Probl Cancer 21:233-300.

Gunther K, Brabletz T, Kraus C, Dworak O, Reymond MA, Jung A, Hohenberger W, Kirchner T, Kockerling F, and Ballhausen WG (1998). Predictive value of nuclear betacatenin expression for the occurrence of distant metastases in rectal cancer. Dis Colon Rectum 41:1256-1261.

Hahne M, Rimoldi D, Schroter M, Romero P, Schreier M, French LE, Schneider P, Bornand T, Fontana A, Lienard D, Cerottini J, and Tschopp J (1996). Melanoma cell expression of Fas(Apo-1/CD95) ligand: Implications for tumor immune escape (see comments). Science 274:1363-1366.

Hashimoto S, Koji T, Kohara N, Kanematsu T, and Nakane PK (1997). Frequency of apoptosis relates inversely to invasiveness and metastatic activity in human colorectal cancer. Virchows Arch 431:241-248.

Hawkins N, Lees J, Hargrave R, O'Connor T, Meagher A, and Ward R (1997). Pathological and genetic correlates of apoptosis in the progression of colorectal neoplasia. Tumour Biol 18:146-156.

Ilyas M, Straub J, Tomlinson IPM, and Bodmer WF (1999). Genetic pathways in colorectal and other cancers. Eur $\mathrm{J}$ Cancer 35:335-351.

Ito Y, Matsuura N, Sakon M, Takeda T, Umeshita K, Nagano H, Nakamori S, Tsujimoto M, Nakahara M, Nakao K, and Monden M (1999). Both cell proliferation and apoptosis significantly predict shortened disease-free survival in hepatocellular carcinoma. $\mathrm{Br} \mathrm{J}$ Cancer 81:747-751.

Jass JR (1986). Lymphocytic infiltration and survival in rectal cancer. J Clin Pathol 39:585-589.

Jass JR (1999). Towards a molecular classification of colorectal cancer. Int J Colorectal Dis 14:194-200.

Kane MF, Loda M, Gaida GM, Lipman J, Mishra R, Goldman H, Jessup JM, and Kolodner R (1997). Methylation of the hMLH1 promoter correlates with lack of expression of hMLH1 in sporadic colon tumors and mismatch repairdefective human tumor cell lines. Cancer Res 57:808-811.

Kaserer K, Schmaus J, Bethge U, Migschitz B, Fasching S, Walch A, Herbst F, Teleky B, and Wrba F (2000). Staining patterns of p53 immunohistochemistry and their biological significance in colorectal cancer. J Pathol 190:450-456.

Kawasaki H, Altieri DC, Lu CD, Toyoda M, Tenjo T, and Tanigawa N (1998). Inhibition of apoptosis by survivin predicts shorter survival rates in colorectal cancer. Cancer Res 58:5071-5074.

Langlois NEI, Lamb J, Eremin O, and Heys SD (1997). Apoptosis in colorectal carcinoma occuring in patients aged 45 years and under: Relationship to prognosis, mitosis and immunohistochemical demonstration of p53, c-myc and bcl-2 protein products. J Pathol 182:392-397.

Loeb LA (1994). Microsattelite instability: Marker of a mutator phenotype in cancer. Cancer Res 54:5059-5063. 
Jonges et al

Lothe RA (1997). Microsattelite instability in human solid tumors. Mol Med Today 2:61-68.

Markowitz S, Wang J, Myerhoff L, Parsons R, Sun L, Lutterbaugh J, Fan RS, Zborowska E, Kinzler KW, Vogelstein B, Brattain MG, and Willson JKV (1995). Inactivation of the type II TGF- $\beta$ receptor in colon cancer cells with microsattelite instability. Science 268:1336-1338.

Naito Y, Saito K, Shiiba K, Ohuchi A, Saigenji K, Nagura H, and Ohtani $H$ (1998). CD8 + T cells infiltrated within cancer cells nests as a prognostic factor in human colorectal cancer. Cancer Res 58:3491-3494.

O'Connell J, O'Sullivan GC, Collins JK, and Shanahan F (1996). The Fas counterattack: Fas-mediated T cell killing by colon cancer cells expressing Fas ligand. J Exp Med 184: 1075-1082.

Rafter J and Glinghammar B (1998). Interactions between the environment and genes in the colon. Eur $\mathrm{J}$ Cancer Prev(7 Suppl 2):S69-S74.

Ropponen KM, Eskelinen MJ, Lipponen PK, Alhava E, and Kosma VM (1997). Prognostic value of tumour-infiltrating lymphocytes (TILs) in colorectal cancer. J Pathol 182:318324.

Sobin LH and Wittekind Ch (1997). Colon and rectum. In: Hermanek P, Hutter RVP, Sobin LH, Wagner G, and Wittekind Ch, editors. TNM Atlas: Illustrated guide to the TNM/ pTNM classification of malignant tumors. New York: Springer, 98-106.
Sugamura K, Makino M, and Kaibara N (1998). Apoptosis as a prognostic factor in colorectal carcinoma. Surg Today 28:145-150.

Svennevig JL, Lunde OC, Holter J, and Bjorgsvik D (1984). Lymphoid infiltration and prognosis in colorectal carcinoma. Br J Cancer 49:375-377.

Tompson CB (1995). Apoptosis in the pathogenesis and treatment of disease. Science 267:386-401.

Tsujitani S, Shirai H, Tatebe S, Sugamura K, Ohfuji S, Gomyo Y, Maeta M, Ito H, and Kaibara N (1996). Apoptotic cell death and its relationship to carcinogenesis in colorectal carcinoma. Cancer 77:1711-1716.

Warren HS and Smyth MJ (1999). NK cells and apoptosis. Immunol Cell Biol 77:64-75.

Watson DS, Brotherick I, Shenton BK, Wilson RG, and Campbell FC (1999). Growth dysregulation and p53 accumulation in human primary colorectal cancer. $\mathrm{Br} \mathrm{J}$ Cancer 80:1062-1068. 